$3^{\text {RD }}$ INTERNATIONAL CONFERENCE ON TRANSFORMATIONS IN ENGINEERING EDUCATIONJANUARY 8 TO 12 , 2016, COLLEGE OF ENGINEERING, PUNE, INDIA

\title{
Availability of Non-Residential Engineering Students by channelized On-Line tools after routine college hours
}

\author{
Dr. Mrs. P. Malathi \\ Vice Principal, DY Patil College of Engineering, Akurdi, Pune, Savitribai Phule Pune University \\ malathijesudason@ymail.com
}

\begin{abstract}
Top ranked engineering colleges in India like IITs and NITs are providing residential campus for students. This gives them distinct advantages for resource availability and mobility $24 \times 7$. Majority of private engineering colleges in Maharashtra are non-residential for students leading to shortage of time for networking, team work related activities. This calls for inculcating an effort to induct a mechanism to cope up these shortcomings.

An attempt has been made in this paper to present a framework of channelized On-Line tools including social media, e-portals, web tutors etc., in an engineering way.
\end{abstract}

Keywords: Social Media, e-portals, non-residential students

\section{Dr. Mrs. P. Malathi}

Vice Principal, DY Patil College of Engineering, Akurdi, Pune, Savitribai Phule Pune University malathijesudason@ymail.com

\section{Introduction}

IITs and NITs are apex engineering institutions in India. In recent years, no. of IITs and NITs are added. About 24 IITs and 31 NITs will be in operation in few years. Apart from strong government financial support, these apex institutions provide On-Campus life to students. This is the distinct feature to students offering residential advantage which is turned into regular studies even after normal working hours [1]. Private engineering institutions in India, even though provide hostel facility, still not able to catch On-Campus life advantage to students that are provided in apex institutions like IITs and NITs. Majority of students in these apex institutes do regular studies even after routine college hours, especially in terms of outcome. Techfest (IIT Bombay) for example, is one of the most popular and largest technical festival in Asia in terms of participants and prize money involved. Even participation in such events requires rigorous preparations, team working and networking by students. This requires beyond working hours and out of box thinking other than standard examination pattern of university curriculum. Majority of Private institutions, students limit engineering studies with respect to class time table and corresponding pedagogies [2].

A group of 82 students, 8 Head of Departments and 10 Senior Faculty members were formed to undergo this study, referred as Study Group (SG).

This paper, describes issues pertaining to non-residential students availability after routine college hours for their professional advantages.

2. Advantages of On-campus Life (Residential Students) Table 1 provides insights of advantages for students having on-campus life listed by Study Group as described in Section 1.

\begin{tabular}{|l|l|l|}
\hline $\begin{array}{l}\text { Sr. } \\
\text { No }\end{array}$ & Characteristics & Description \\
\hline 1$)$ & Networking & $\begin{array}{l}\text { Classmates spending time } \\
\text { outside classroom } \\
\text { together, is crucial for } \\
\text { teambuilding, innovative } \\
\text { way of solving } \\
\text { assignments. }\end{array}$ \\
\hline
\end{tabular}




\begin{tabular}{|c|c|c|}
\hline $\begin{array}{l}\text { Sr. } \\
\text { No }\end{array}$ & Characteristics & Description \\
\hline 2) & $\begin{array}{l}\text { Less } \\
\text { Distraction }\end{array}$ & $\begin{array}{l}\text { To and fro travelling time } \\
\text { will be much reduced. } \\
\text { Non-academic issues will } \\
\text { be less exposed to } \\
\text { students }\end{array}$ \\
\hline 3) & $\begin{array}{l}\text { More Hands } \\
\text { On }\end{array}$ & $\begin{array}{l}\text { Students devoting more } \\
\text { time to instruments, } \\
\text { accessories will lead to } \\
\text { more hands on of } \\
\text { instruments }\end{array}$ \\
\hline 4) & Diversity & $\begin{array}{l}\text { Students can spend more } \\
\text { time on academic } \\
\text { diversity and generation } \\
\text { of interdisciplinary ideas }\end{array}$ \\
\hline 5) & $\begin{array}{l}\text { Community } \\
\text { Living }\end{array}$ & $\begin{array}{l}\text { Students can be better } \\
\text { exposed to professional } \\
\text { ethics and mannerism }\end{array}$ \\
\hline 6) & $\begin{array}{l}\text { Enhanced } \\
\text { Profiles }\end{array}$ & $\begin{array}{l}\text { Students can therefore } \\
\text { enhance their profiles } \\
\text { through } \\
\text { extra-curricular activities } \\
\text { apart from academics, } \\
\text { more appealing to } \\
\text { recruiters. }\end{array}$ \\
\hline 7) & $\begin{array}{l}\text { Research } \\
\text { Practices }\end{array}$ & $\begin{array}{l}\text { Students spending after } \\
\text { working hours timings in } \\
\text { laboratories will enhance } \\
\text { research formulation. }\end{array}$ \\
\hline 8) & $\begin{array}{l}\text { Exposure to } \\
\text { Professional } \\
\text { Environment }\end{array}$ & $\begin{array}{l}\text { Students will be more } \\
\text { exposed improvised } \\
\text { communication skill. }\end{array}$ \\
\hline
\end{tabular}

Table 2.1: Residential Students Advantages

\section{On-line learning Tools}

Majority of professionals feels, the advent of internet has lead to more distraction to students. This is more worsened by the use of social media. Disadvantages like frauds, spams, negativity consequences, non-academic usages can be faced. However, even though truth lies in above, still the advantages cannot be denied. Advantages like Networking, Reach to recruiters, improvisation of perception, personal characteristics build up etc.

The use of internet, social media can provide distinct advantages if channelized and coordinated properly.

Online teaching strategies help a teacher save his valuable time by incrementally adding and revising his content, which allows him to recollect a previously taught course easy learning from student's perspective Students who feel missed out during lectures can get added opportunity to rejoin in next lecture due to easy accessibility [3].

A wide variety of ICTs should be designed to improve learning experiences by providing more personalized and effective learning environments for students [4].

A series of discussions with Students and Teachers were conducted to know how students approach to studies and professional outcomes to design these ICTs for enhancement. Following can be classified use of On-line learning tools along with its recommended usages.

\begin{tabular}{|l|l|l|}
\hline $\begin{array}{l}\text { Sr. } \\
\text { No }\end{array}$ & $\begin{array}{l}\text { On-line } \\
\text { learning Tools }\end{array}$ & Characteristics \\
\hline 1$)$ & You-Tube & $\begin{array}{l}\text { Dynamic Learning, } \\
\text { Useful for strengthening }\end{array}$ \\
\hline
\end{tabular}

\begin{tabular}{|c|c|c|}
\hline $\begin{array}{l}\text { Sr. } \\
\text { No }\end{array}$ & $\begin{array}{l}\text { On-line } \\
\text { learning Tools }\end{array}$ & Characteristics \\
\hline & & $\begin{array}{l}\text { subject content and actual } \\
\text { viewing of instruments } \\
\text { working. }\end{array}$ \\
\hline 2) & $\begin{array}{l}\text { Internet sites } \\
\text { like } \\
\text { Wikipedia, } \\
\text { NPTEL, } \\
\text { Slideshare, } \\
\text { Spoken } \\
\text { tutorials etc }\end{array}$ & $\begin{array}{l}\text { Helpful in design and } \\
\text { development of solutions } \\
\text { through } \\
\text { method. }\end{array}$ \\
\hline 3) & PODCAST & $\begin{array}{l}\text { Digital media containing } \\
\text { episodes of videos and } \\
\text { audios will be useful in } \\
\text { revising the subjects }\end{array}$ \\
\hline 4) & $\begin{array}{l}\text { Dedicated } \\
\text { softwares like } \\
\text { dypcoeakprod } \\
\text { uction.myexa } \\
\text { mo.com } \\
\end{array}$ & $\begin{array}{l}\text { Can be used for online } \\
\text { practice tests, aptitude } \\
\text { test preparations }\end{array}$ \\
\hline 5) & $\begin{array}{l}\text { Social Media } \\
\text { like } \\
\text { Facebook, } \\
\text { Whatsapp and } \\
\text { Telegram }\end{array}$ & $\begin{array}{l}\text { Can be used for } \\
\text { networking, } \\
\text { teambuilding, innovative } \\
\text { ways of sharing questions } \\
\text { and answers to revive } \\
\text { pedagogy. }\end{array}$ \\
\hline
\end{tabular}

Table 3.1: Online Learning Tools

3.1 Implementation Framework

Case study is taken by SG for implementation of On-Line tools and its impact analysis is carried out. In private engineering colleges a class strength is ranging upto 100 students maximum and upto80 students in general. In todays era, whatsapp and Telegram groups above maximum members can be easily accommodated. We had also made 3 groups of faculties across the institution to facilitate collaborative sharing and exchange of ideas rapidly. Facebook account of department can add all stakeholders listed in NBA Tier II programs for facilitating continual interaction providing distinct advantages to Institution. SG recommends following implementation framework.

\begin{tabular}{|c|c|c|c|}
\hline $\begin{array}{l}\text { Sr. } \\
\text { No. }\end{array}$ & Activity & Task Taken & Impact \\
\hline 1) & $\begin{array}{l}\text { Telegram } \\
\text { Groups of } \\
\text { Students for } \\
\text { each course }\end{array}$ & $\begin{array}{lr}\text { Exchange of } \\
\text { notes, ppts, } 1 \\
\text { oral question } \\
\text { per day, } \\
\text { Current } \\
\text { research }\end{array}$ & $\begin{array}{l}\text { More } \\
\text { participation } \\
\text { of students } \\
\text { after working } \\
\text { hours }\end{array}$ \\
\hline 2) & $\begin{array}{l}\text { Whats app } \\
\text { group for } \\
\text { students for } \\
\text { each class }\end{array}$ & $\begin{array}{l}\text { Exchange of } \\
\text { administrative } \\
\text { and official } \\
\text { information }\end{array}$ & $\begin{array}{l}\text { Students } \\
\text { exchange } \\
\text { ideas and } \\
\text { communicate }\end{array}$ \\
\hline 3) & $\begin{array}{l}\text { Facebook } \\
\text { Account } \\
\text { (Not just } \\
\text { page) }\end{array}$ & $\begin{array}{lr}\text { All students } \\
\text { are added } \\
\text { including } \\
\text { alumni } \\
\text { recruiters. and } \\
\text { activities } \\
\text { images } \\
\text { posted. }\end{array}$ & $\begin{array}{l}\text { Sharing with } \\
\text { Alumni } \\
\text { helpful in } \\
\text { summer } \\
\text { internship for } \\
\text { students. } \\
\text { Showcasing } \\
\text { talents helpful } \\
\text { for students to } \\
\text { create } \\
\text { positive }\end{array}$ \\
\hline
\end{tabular}




\begin{tabular}{|l|l|l|l|}
\hline $\begin{array}{l}\text { Sr. } \\
\text { No. }\end{array}$ & Activity & Task Taken & Impact \\
\hline 4$)$ & $\begin{array}{l}\text { Whatsapp } \\
\text { group for } \\
\text { Parents for } \\
\text { each class }\end{array}$ & $\begin{array}{l}\text { Students } \\
\text { characteristic } \\
\text { like } \\
\text { attendance, } \\
\text { award wining, } \\
\text { test result }\end{array}$ & $\begin{array}{l}\text { Profile Pressure } \\
\text { to students to } \\
\text { perform }\end{array}$ \\
\hline 5$)$ & $\begin{array}{l}\text { You-tube } \\
\text { clubs }\end{array}$ & $\begin{array}{l}\text { Online video } \\
\text { streaming on } \\
\text { topics declared } \\
\text { in Whatsapp } \\
\text { and students } \\
\text { prepare one } \\
\text { page report }\end{array}$ & $\begin{array}{l}\text { Participation } \\
\text { of Students } \\
\text { has increased } \\
\text { in college } \\
\text { level } \\
\text { activities and } \\
\text { research } \\
\text { activities }\end{array}$ \\
\hline 6$)$ & $\begin{array}{l}\text { Exploration } \\
\text { of Websites } \\
\text { like TATA } \\
\text { Motors, } \\
\text { TCS etc }\end{array}$ & $\begin{array}{l}\text { Students } \\
\text { explore } \\
\text { websites of } \\
\text { companies } \\
\text { every Saturday } \\
\text { and prepare } \\
\text { one } \\
\text { report and } \\
\text { submit and }\end{array}$ & $\begin{array}{l}\text { Students are } \\
\text { now more } \\
\text { cautious } \\
\text { regarding } \\
\text { skills required } \\
\text { to } \\
\text { inducted in a } \\
\text { company and } \\
\text { trying to } \\
\text { inculcate } \\
\text { them during } \\
\text { studies }\end{array}$ \\
\hline 7$)$ & $\begin{array}{l}\text { e-exam } \\
\text { portal }\end{array}$ & $\begin{array}{l}\text { Practice } \\
\text { aptitude tests } \\
\text { once in a week } \\
\text { creating are } \\
\text { positive } \\
\text { profile by } \\
\text { practicing on } \\
\text { regular basis }\end{array}$ \\
\hline
\end{tabular}

Table 4.1: Proposed Framework

All the above groups and tasks were carefully monitored by faculty coordinator to waive of disadvantages mentioned in section 3 of this paper.

\section{Transformations observed (Conclusion)}

As the students are now connected even after routine working hours, following transformations are observed.

1) Increase in Average Theory Attendance

2) Increase in Performance in Test/Prelim

3) Increase in Activity Participation

4) Delivery of e-contents via telegram groups had created positive impact in teaching-learning process as students read before attending the classes.

\section{Acknowledgement:}

The author will like to thank Hon. Chairman, Shri. Satej D. Patil, Campus Director Col. S. K. Joshi and Principal, Dr. B.S. Balapgol for their continual support and guidance for this transformation framework.

The author would also like to express sincere thanks to anonymous reviewers for enhancing the framework of this paper.

The author also will like to acknowledge the contribution in terms of discussions, with HODs and senior faculty members at various stages of development of this framework.
1. https://en.wikipedia.org/wiki/Indian_Institutes_of_Techn ology https://en.wikipedia.org/wiki/National_Institutes_of_Tec hnology

2. Deepak B. Pathak(2014), Adopting MOOCs for Quality Engineering Education in India, Proceedings of the International Conference on Transformations in Engineering Education, Springer India,11-23

3. KC Chilukuri, KVL Raju (2014), PPP: A Paradigm for online education in engineering colleges, Proceedings of the International conference on Transformations in Engineering Education, Springer India, 315-322

4. S. Farrell, H.J. Hoyer, D. M. Fraser(2014), Transformations in Engineering Education Globally, Proceedings of the International conference on Transformations in Engineering Education, Springer India, 3-7

5. Aziz, E. (2011). Teaching and learning enhancement in undergraduate machine dynamics. Computer Applications in Engineering Education, 19(2), 244-255.

6. Deliktas, B. (2011). Computer technology for enhancing teaching and learning modules of engineering mechanics. Computer Applications in Engineering Education, 19, 421-432.

7. Dolecek, G. (2011). MATLAB-based program for teaching autocorrelation function and noise concepts. IEEE Transaction on Education, 99, 1-8. Fraser,

8. D.M., Pillay, R., Tjatindi, L., Case, J.M, 2007. Enhancing the Learning of Fluid Mechanics Using Computer Simulations. Journal of Engineering Education. 96 (3), 381-388

9. Goeser, P., Johnson, W., Hamza-Lup, F., Schaefer, D. (2011). View - A virtual interactive web-based learning environment for engineering. Advances in Engineering Education, 1-24. Khan,

10.F., Birchfield, N. and Singh, K. V. (2012). Revitalizing the engineering curriculum through studio based Instruction. Proceedings of the

11. ASME International Mechanical Engineering Congress and Exposition (IMECE-12), Paper Number: IMECE2012-89547, Houston, TX. 131-138

12.Downey, Gary L. et al. "The Globally Competent Engineer: Working Effectively with People who Define Problems Differently."Journal of Engineering Education 95.2 (2006): 107-122.

13.Deardorff, Darla K. "Theory Reflections: Intercultural Competence Framework/Model." (2006).

14.Lohmann, Jack R., Rollins, Howard A., and Hoey, J. Joseph. "Defining, Developing and Assessing Global Competence in Engineers." European Journal of Engineering Education 31.1 (2006): 119-131.

15.Rubin, Donald L. and Matthews, Paul H. "Learning Outcomes Assessment: Extrapolating from Study Abroad to International Service-Learning." Journal of Higher Eduation Outreach and Engagement 17.2 (2013): 67-86.

16. Sadrozinski, Renate. "Evaluative Framework for International Collaboration." (2008).

\section{References}

